\title{
CONTINUOUS PROFESSIONAL DEVELOPMENT ORIENTATION IN THE FIELD OF INFORMATION AND COMMUNICATION TECHNOLOGY
}

\section{Ondřej NEUMAJER}

\begin{abstract}
The paper summarizes results of the research in which the analysis of submitted applications for accreditation in the continuous professional development of teachers dealing with information and communication technologies (ICT) was realised. These applications for accreditation are tracked separately: educational programs on basic ICT literacy, the ICT methodology, pedagogical documentation and programs dealing with computer science, programming and algorithms. The results should help in designing and shaping the new career system of continuous professional development of teachers.
\end{abstract}

Key words: continuous professional development, information and communication technologies, computer science, research, didactics, career professional development

\section{ZAMĚŘENÍ DALŠÍHO VZDĚLÁVÁNÍ UČITELŮ V OBLASTI ICT}

Resumé: Příspěvek shrnuje výsledky výzkumu, ve kterém byla provedena analýza předkládaných žádostí o akreditace dotýkajících se problematiky informačních a komunikačních technologií v systému dalšího vzdělávání pedagogických pracovníků. Analýza databáze žádostí akreditační komise MŠMT na podzim 2012 umožňuje zmapovat kompletní nabídku vzdělávání, která je posléze předkládána učitelům $\mathrm{v}$ celorepublikovém kontextu. Odděleně jsou sledovány vzdělávací programy zaměřené na podporu základní ICT gramotnosti, didaktiku práce s ICT, vedení pedagogické dokumentace a programy zabývající se informatikou, programováním a algoritmizací. Analýza nabídky by měla posloužit při rozhodování o směrování a formování kariérního systému dalšího vzdělávání.

Klíčová slova: další vzdělávání pedagogických pracovníků, ICT, informatika, výzkum, didaktika, kariérní systém

\section{1 Úvod}

Př́ispěvek se zaměřuje na některé charakteristiky současné nabídky vzdělávání pedagogických pracovníků v oblasti informačních a komunikačních technologií (ICT), které mohou učitelé regionálního školství využívat pro svůj profesní rozvoj.

\section{Systém dalšího vzdělávání}

Další vzdělávání pedagogických pracovníků (DVPP) vychází ze Zákona o pedagogických pracovnících č. 563/2004 Sb. a z vyhlášky 317/2005 Sb. o DVPP, akreditační komisi a kariérním systému pedagogických pracovníků. Požádat Ministerstvo školství, mládeže a tělovýchovy (MŠMT) o akreditaci vzdělávacího programu může každá organizace, která splní požadované kvalifikační předpoklady. Její žádost s podrobným rozpisem vzdělávacích programů následně projde posouzením akreditační komise MŠMT. Důvodem vzdělavatelů pro podání žádosti o udělení akreditace je možnost škol a školských zařízení hradit takto akreditované vzdělávání pedagogických pracovníků z prostředků státního rozpočtu, které jsou za tímto účelem školám k dispozici.

Pro ilustraci trendu vývoje posledních let je možné citovat z poslední výroční zprávy České školní inspekce za školní rok 2010/2011 [1], ze které vyplývá, že průměrná roční částka na jednoho pedagogického pracovníka určená na DVPP byla $\mathrm{v}$ roce 2010 pro mateřské školy 537 Kč, pro základní školy 715 Kč a pro střední školy $472 \mathrm{Kč}$. Oproti předchozímu roku se fakticky jednalo v průměru o pokles na polovinu.

Výzkum zaměření dalšího vzdělávání učitelů v oblasti ICT proběhl v návaznosti na výzkum realizovaný autorem v první polovině roku 2012, který se zabýval strukturou nabídky vzdělávacích programů zhlediska jejich pokročilosti, resp. inovativnosti [2]. Základní použité charakteristiky (zejm. rozdělení žadatelů do př́slušných kategorií) použité $\mathrm{v}$ tomto výzkumu byly využity i nyní.

\section{Kategorie vzdělávacích programů}


Akreditační komise DVPP jedná pětkrát v průběhu školního roku, tedy každý jeho druhý měsíc. Komise je rozdělena do několika subkomisí. Členům subkomise ICT jsou přidělovány pouze takové žádosti, které se dotýkají problematiky informatiky a ICT.

Akreditační komise zkoumá předloženou žádost na základě kritérií, resp. jednotlivých náležitostí žádosti. Požadované náležitosti jsou uvedeny na webu MŠMT $\mathrm{v}$ sekci věnované akreditacím [3]. Je důležité uvést, že nelze zajistit, zda je obsah žádosti ve finále realizován $\mathrm{v}$ té podobě, $\mathrm{v}$ jaké byl předložen $\mathrm{k}$ akreditaci. Dodržení tohoto požadavku je zodpovědností předkladatele.

Za účelem rozdělení žádostí dle obsahového zaměření do skupin vytvořil autor výzkumu následující čtyři kategorie:

\begin{tabular}{|l|l|}
\hline \multicolumn{1}{|c|}{$\begin{array}{c}\text { kategorie } \\
\text { vzdélávacího } \\
\text { programu }\end{array}$} & \multicolumn{1}{c|}{ př́klady a komentáre } \\
\hline $\begin{array}{l}\text { 1. vzdělávací } \\
\text { programy } \\
\text { podporující rozvoj } \\
\text { uživatelských } \\
\text { dovedností } \\
\text { (ICT gramotnost) }\end{array}$ & $\begin{array}{l}\text { především základní } \\
\text { školení funkčních } \\
\text { dovedností, ovládání } \\
\text { základního software } \\
\text { a internetu (kancelářské } \\
\text { balíky, základy internetu } \\
\text { atp.), SIPVZ školení } \\
\text { úrovně Z, P0, psaní na } \\
\text { klávesnici, základy } \\
\text { počítačové grafiky atp. }\end{array}$ \\
\hline $\begin{array}{l}\text { 2. vzdělávací } \\
\text { programy zaměřené } \\
\text { na didaktiku práce } \\
\text { s ICT a výukové } \\
\text { ICT aktivity }\end{array}$ & $\begin{array}{l}\text { tvorba digitálních } \\
\text { učebních materiálů } \\
\text { (DUM), práce } \\
\text { s interaktivní tabulí, } \\
\text { eTwinning, projektová } \\
\text { výuka s ICT, e-learning }\end{array}$ \\
\hline $\begin{array}{l}\text { 3. vzdělávací } \\
\text { programy zaměřené } \\
\text { na informatiku, } \\
\text { zejm. algoritmizaci, } \\
\text { programování či } \\
\text { databáze }\end{array}$ & $\begin{array}{l}\text { programování v různých } \\
\text { programovacích } \\
\text { jazycích, semináře } \\
\text { k programovatelným } \\
\text { robotickým stavebnicím } \\
\text { atp. }\end{array}$ \\
\hline $\begin{array}{l}\text { 4. vzdělávací } \\
\text { programy zaměřené } \\
\text { na zajištění } \\
\text { administrativního } \\
\text { vedení pedagogické } \\
\text { dokumentace } \\
\text { za pomoci ICT }\end{array}$ & $\begin{array}{l}\text { práce se software } \\
\text { zaměřeným na vedení } \\
\text { pedagogické } \\
\text { dokumentace, školní } \\
\text { informační systémy, } \\
\text { internetovou prezentaci } \\
\text { školy, školní matriku, } \\
\text { výkaznictví, novou } \\
\text { legislativu dotýkající se }\end{array}$ \\
\hline
\end{tabular}

\begin{tabular}{|l|l|}
\hline & dokumentace s ICT atp. \\
\hline $\begin{array}{l}\text { Tabulka 1: Použitá kategorizace vzdélávacích } \\
\text { programů }\end{array}$ & \\
\hline
\end{tabular}

Takto pojatá typologie jednoznačně nevyznačuje ostré hranice mezi jednotlivými kategoriemi, ty mají nezřetelný předěl. Každá žádost musí být posuzována individuálně, univerzální jednoznačné vymezení vyjádřené formou definice není prakticky možné stanovit. $\mathrm{V}$ několika př́padech, ve kterých bylo obsahové posouzení obzvláště obtížné, bylo při provádění analýzy nutné přistoupit členy subkomise ICT ke vzájemným konzultacím. Výsledkem takových diskuzí pak je rozšsiření jednotlivých kategorií o př́klady a komentáře (viz tabulka).

\section{Parametry zkoumaného vzorku}

Do zkoumaného vzorku byly zahrnuty všechny žádosti, které subkomise ICT obdržela na svém říjnovém jednání: jednalo o 286 vzdělávacích programů, které předložilo 50 institucí. Toto množství představuje cca jednu pětinu všech žádostí, které subkomise ICT v roce 2012 posuzovala.

Pro zjištění bližších informací o vazbě poskytovatelů vzdělávacích programů na charakter kurzů byli žadatelé o akreditaci rozděleni dle právní formy a charakteru zřizovatele do čtyř kategorií:

\begin{tabular}{|c|c|c|}
\hline $\begin{array}{c}\text { kategorie } \\
\text { žadatele }\end{array}$ & príklad & $\begin{array}{c}\text { podil } \\
\text { předklá } \\
\text { daných } \\
\text { program } \\
\stackrel{\circ}{u} \\
\end{array}$ \\
\hline škola & $\begin{array}{l}\text { MŠ, ZŠ, SŠ, } \\
\text { VOŠ, VŠ }\end{array}$ & $22 \%$ \\
\hline $\begin{array}{l}\text { příspěvková } \\
\text { organizace } \\
\text { MŠMT či kraje }\end{array}$ & $\begin{array}{l}\text { NIDV, KVIC, } \\
\text { DDM, středisko } \\
\text { služeb školám }\end{array}$ & $18 \%$ \\
\hline $\begin{array}{l}\text { nevládní a } \\
\text { nestátní } \\
\text { organizace, } \\
\text { nezisková } \\
\text { organizace }\end{array}$ & o. p. s., o. s. atp. & $12 \%$ \\
\hline $\begin{array}{l}\text { komerční } \\
\text { společnost }\end{array}$ & $\begin{array}{l}\text { a. s., s. r. o., } \\
\text { OSVČ atp. }\end{array}$ & $48 \%$ \\
\hline
\end{tabular}

Tabulka 2: Žadatelé dle právní formy a charakteru zrrizovatele

Pro srovnání může být zajímavé uvést, že podíl zastoupení předložených vzdělávacích 
programů státních a krajských (18\%) a nestátních organizací $(12 \%)$ byl zcela identický, jako v předchozích dvou jednáních komise (v dubnu a červnu 2012). Rozdíly v podílu předkládaných žádostí ale zaznamenaly školy (snížení na $22 \%$ v říjnu oproti $30 \%$ v dubnu a červnu) a komerční společnosti (zvýšení na $48 \%$ v ř́ínu oproti $40 \%$. v dubnu a červnu). Zmenšení podílu žádostí škol na úkor zvýšení podílu žádostí komerční společností může být zpo̊sobeno letními prázdninami, tedy obdobím, kdy učitelé čerpají povinně významnou část dovolené a tudíž na přípravu vzdělávacích aktivit nemají dostatek času. Pro další měsíce nebyla statistika zpracována.

\section{Výsledky výzkumu}

Zjištěné zastoupení jednotlivých kategorií vzdělávacích programů je patrné $\mathrm{z}$ následujícího grafu:

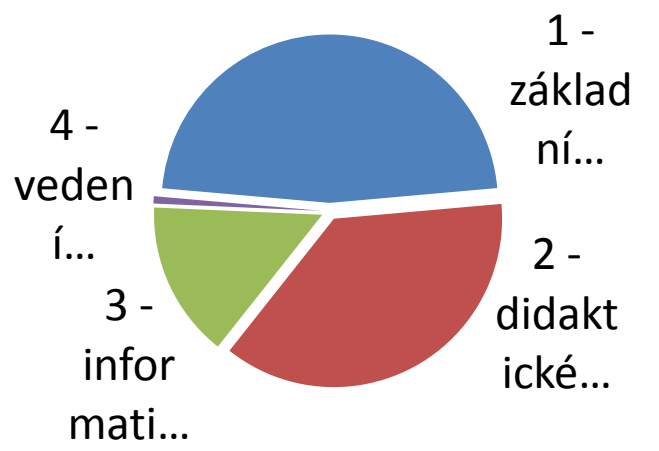

Obr. 1 Rozložení vzdělávacích programů do jednotlivých kategorií

Téměř polovina $(47 \%)$ všech předložených vzdělávacích programů jsou ty, které podporují rozvoj uživatelských ICT dovedností, tedy to, co je zpravidla označováno jako ICT gramotnost. $37 \%$ ze všech žádostí tvoří vzdělávací programy zaměřené na didaktiku práce $\mathrm{s}$ ICT a výukové ICT aktivity. Mezi nimi jednoznačně převažují vzdělávací programy zaměřené na vytváření digitálních učebních materiálů (DUM) a práci s interaktivní tabulí. Hlavním důvodem způsobujícím masivní akcentaci těchto seminářů a workshopů způsobil probíhající dotační program MŠMT EU peníze školám (Oblast podpory 1.4 - zlepšení podmínek pro vzdělávání). Ten přinesl mimopražským základním školám 4,2 a středním školám 1,4 miliard Kč, $\mathrm{z}$ čehož téměř polovina byla směrována na ICT šablony [4].

Při hlubším zkoumání obsahu vzdělávacích programů, které svým deklarovaným zaměřením spadají do této kategorie, lze dojít $\mathrm{k}$ závěru, že ve skutečnosti je $\mathrm{z}$ nich jen malá část skutečně věnována uplatňování didaktických zásad při tvorbě učebních materiálů. Významná část těchto vzdělávacích programů se ve svých cílech a postupech zaměřuje na popis technických vlastností nástrojů pro vytváření daných materiálů (nejčastěji DUM, objektı̊ SMART Notebook či ActivInspire) a jen okrajově na samotné didaktické zásady a charakteristiky vzniku takových materiálů. Tyto vzdělávací programy ve své většině učí učitele obecně pracovat s autorskými nástroji, nežli aby jim zprostředkovávali a přibližovaly didaktické aspekty tvorby materiálů.

Vzdělávací programy zaměřené na informatiku, algoritmizaci, programování či výuku databází jsou zastoupeny $15 \%$. Zbylé jedno procento náleží vzdělávacím programům soustřed’ujícím se na zajištění administrativního vedení pedagogické dokumentace za pomoci ICT. Mezi ně zpravidla patří práce se školními informačními systémy či vytváření internetových prezentací škol. Jistým překvapením je skutečnost, že jediné dva vzdělávací programy $\mathrm{v}$ této kategorii nepředložily komerční společnosti (např. autoři daných software), ale státní a krajské organizace. Tento fakt může být ale ovlivněn malým počtem žádostí $\mathrm{v}$ této kategorii vzdělávacích programů.

Rozložení vzdělávacích programů do jednotlivých kategorií dle skupin jednotlivých žadatelů je patrné z následujícího grafu:

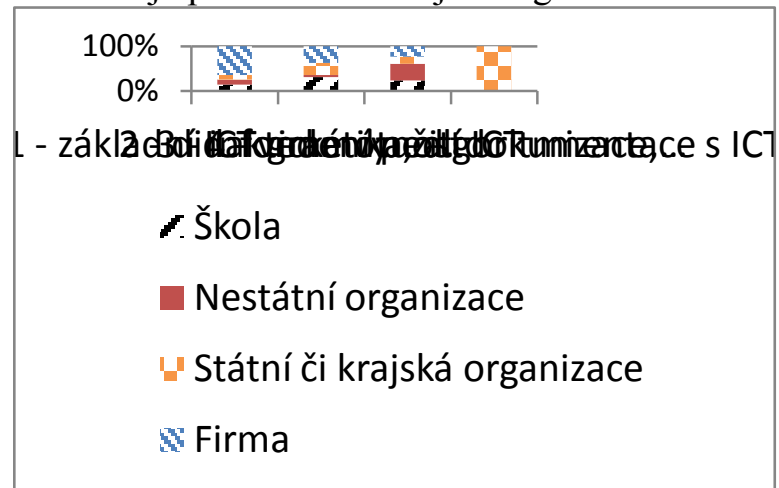

\section{Obr. 2 Rozložení do jednotlivých kategorií dle skupin jednotlivých žadateli̊}

Graf ilustruje nerovnoměrné zastoupení ve struktuře nabídky jednotlivých kategorií ICT vzdělávání poskytovateli vzdělávání. Komerční společnosti nabízejí především vzdělávání v základních uživatelských dovednostech a se zvyšující se didaktickou složitostí či odborností vzdělávacích programů klesá i rozsah jejich nabídky. Naopak nestátní a neziskové organizace 
se nejvíce zaměřují na problematiku informatiky a algoritmizace.

\section{Význam analýzy}

Provedená obsahová analýza předkládaných vzdělávacích programů prinnáší výsledky, které mohou být zajímavé např́klad pro žadatele o akreditaci vzdělávacích programů a směrování jejich vzdělávací nabídky pedagogickým pracovníkům. Především by ale měly být podkladem pro odborný diskurz o směrování institucionalizovaného systému dalšího vzdělávání pedagogických pracovníků. Autor si není vědom žádné jiné analýzy vzdělávací nabídky realizované $\mathrm{v}$ systému DVPP a to nejen $\mathrm{v}$ oblasti ICT. Pro jednání o změnách v kariérním systému pedagogických pracovníků by mělo být např́klad důležité zjištění, že pouhých $22 \%$ předkládaných vzdělávacích programů pochází od škol (mateřských, základních, středních, vyšších odborných a vysokých).

\section{Literatura}

[1] Výroční zpráva ČŠI za školní rok 2010/2011. Praha: Česká školní inspekce. 2012. Dostupné on-line http://www.csicr.cz/cz/Dokumenty/Vyrocnizpravy/Vyrocni-zprava-CSI-za-skolni-rok-20102011.

[2] NEUMAJER, O. Výzkum struktury vzdělávání učitelů $\mathrm{v}$ oblasti ICT v roce 2012 in Sbornik mezinárodni konference ICT ve vzděláváni. [v tisku]. Olomouc: UPOL, 2013.
[3] Akreditace vsystému DVPP. Praha: Ministerstvo školství, mládeže a tělovýchovy, 2012. Dostupné on-line http://www.msmt.cz/vzdelavani/akreditace-vsystemu-dvpp.

[4] Tisková zpráva. Program „EU penize školám " zaznamenal úspěch. Praha: Ministerstvo školství, mládeže a tělovýchovy, 16. 10. 2012. Dostupné on-line http://www.msmt.cz/strukturalni-fondy/programeu-penize-skolam-zaznamenal-uspech.

[5] RAMBOUSEK, V., HUSTOPECKÝ, J., NEUMAJER, O., $\quad$ MUDRÁK, D. PROCHÁZKA, J., ŠTÍPEK, J. Výzkum informačni výchovy na základnich školách. Praha: Koniáś, 2007. 360 stran. ISBN 80-8694810-2.

[6] STARÝ, K., DVOŘÁK, D., GREGER, D., DUSCHINSKÁ, K. Profesní rozvoj učiteli. Podpora učitelů pro zlepšsováni výsledků žáků. Praha: Karolinum, 2012. ISBN 978-80-2462087-9.

PhDr. Ondřej Neumajer, Ph.D.

Katedra informačních technologií a technické výchovy

Pedagogická fakulta UK

M. D. Rettigové 4

11639 Praha 1

Tel: +420602 763275

E-mail: ondrej@neumajer.cz

Www pracoviště: http://it.pedf.cuni.cz/ 